\title{
GENETICAL AND PHYSIOLOGICAL VARIABILITY BETWEEN TAMARIX APHYLLA AND TAMARIX NILOTICA SPECIES OF OYOUN MOUSA REGION, SINAI, EGYPT
}

\author{
Laila E. Mekki* and El-Sayed A. El-Meleigy \\ Departement of Botany, Faculty of Science, Suez Canal University, \\ Ismailia, Egypt \\ *E-mail: lhmmekki_dr@hotmail.com
}

\begin{abstract}
7 amarix aphylla trees occupy a distinct zone along the sand 1 dune in Oyoun Mousa region. Genetical and physiological studies on the oldest tree $T$. aphylla and the T. nilotica species in the same region were carried out. Electrophoretic analysis of total soluble protein (SDS-PAGE) and some isoenzymes; such as acid phosphatase (ACPH), esterase (EST), peroxidase (POD) and 6- phosphogluconate dehydrogenase (6PGD) revealed that $T$. aphylla exhibited higher number of polypeptides and isoformes. This finding might suggest that $T$. aphylla plants are more tolerant to salt stress than T. nilotica. This could be accomplished by increasing the capacity of antioxidative system, synthesis of new protein and isoenzymes, which could in turn contribute to some defense mechanisms of tolerant plant. Random Amplified Polymorphic (RAPD) DNA markers were used to measure genetic diversity of the two species. A total of 50 amplified bands were scored with the used of 8 RAPD primers, with a mean of 6.2 amplified bands per primer, and 66\% (33 bands) of polymorphic bands were found. The use of DNA markers, OPA-7, OPA-10, OPA-15 and OPB-4 distinguished bands with size ranging from 1655 to $2500 \mathrm{bp}$ in $T$. aphylla only and absent in T. nilotica.
\end{abstract}

Keywords: Oyoun Moussa, Tamarix, RAPD, isoenzymes, SDS-PAGE

Tamarix belonging to family Tamaricaceae is represented by several species in Egypt. The most common and widespread species are T. nilotica and T. aphylla (Western and McLeod Source, 1995).

Oyoun Mousa or "Springs of Moses" is located about $20 \mathrm{~km}$ south Ahmed Hamdi Tunnel, which connects the mainland of Egypt with Sinai. In this region, a very old giant $T$. aphylla trees community occupy a large area. Another species; T. nilotica is also in the same area and the road from 
Ahmed Hamdi Tunnel to the springs. Salt and osmotic stress are two general limiting factors for plant growth and development. Both factors can induce oxidative damage and affect several physiological processes (Borsani et al., 2001). Throughout evolutionary history, plants have evolved different defense strategies to adapt to stress by regulating many genes involved in stress-tolerance.

Tamarix plants are adaptable halophytic and / or xerophytic trees or shrubs (Brock, 1994). They excrete salt from their leaves and branches. They are highly tolerant to various stressful conditions, such as heat, cold, drought, flood, and high concentrations of dissolved solids (Di Tomaso, 1996; Cleverly et al., 1997; Glenn et al., 1998; Vandersande et al., 2001; Glenn and Nagler, 2005).

T. aphylla is more common in the eastern desert in wadis and tunnels where there is adequate water for deep rooting system. Tamarix tree has a deep and extensive root system, about $10 \mathrm{~m}$ vertically and $34 \mathrm{~m}$ horizontally (Di Tomaso, 1996). T. nilotica is a common shrub in the littoral and inland salt marshes of Egypt. Its shrub types occur on sand dunes and parts of the salt marshes with the deepest sand deposits, but they are more vigorous on the sand dunes than in the salt marshes (Zahran and Willis, 2008).

Approximately $20 \%$ of the world's cultivated land is affected by salinity and nearly half of all irrigated lands are affected by salinity (Sairam and Tyagi, 2004 and Huang et al., 2009). Increasing salinity causes salt stress in most plants and this stress affects protein synthesis and can seriously disrupt normal metabolism through oxidative damages of lipids, proteins and nucleic acids (Meloni et al., 2003).

Plants posses a number of antioxidant systems that protect them from these potential cytotoxic effects. Antioxidant enzymes are the most important components in the scavenging system of reactive oxygen species (ROS) (Meloni et al., 2003). Salt- tolerant plants increase their antioxidant enzyme activities and antioxidant contents in response to salt treatment (Shalata et al., 2001 and Demiral and Turkan, 2005).

Salinity tolerance comes from genes that limit the rate of salt uptake from the soil and the transport of salt throughout the plant, adjust the ionic and osmotic balance of cells and the onset of senescence (Munns, 2005).

Molecular markers can be extremely useful in assessing polymorphism in plants. Among these markers, RAPD is most widely used, because it allows a rapid and inexpensive assay with a large number of markers (Welsh and MacClland, 1990 and Williams et al., 1990).

The objective of the present study is to describe some evidence toward genomic characteristic variability between the giant old tree $T$. aphylla and the other species; T. nilotica found in Oyoun Mousa region. 


\section{MATERIALS AND METHODS}

The region of the present study is located South Ahmed Hamdi Tunnel at Oyoun Mousa Oasis, Sinai, Egypt. There is a tamarix community that has grown up around the springs composed of giant old T. aphylla trees and T. nilotica species, Fig. (1). T. nilotica is also found on the road from Ahmed Hamdi Tunnel to Oyoun Moussa region.

The samples 1, $2 \& 3$ were collected from different sites of the old giant tree of T. aphylla. Samples $4,5 \& 6$ were collected from three different $T$. nilotica trees in the same region. For each sample, at least 3 individual branches were collected and mixed together.

\section{Estimation of Photosynthetic Pigments}

Six fresh leaf samples (1 g fresh wt. each) were collected, washed and used for photosynthetic pigments estimation. Samples were ground in 5 $\mathrm{ml} 80 \%$ acetone. The homogenate was centrifuged at $5000 \mathrm{rpm}$ for 5 minutes. The supernatant absorbance was measured at 452.5, 644 and 663 $\mathrm{nm}$ against the solvent blank for estimation of chlorophylls a, b and carotenoids, respectively. Contents of chlorophylls a and b as well as total carotenoids were expressed as $\mu \mathrm{g} / \mathrm{g}$ tissue (Metzner et al., 1965).

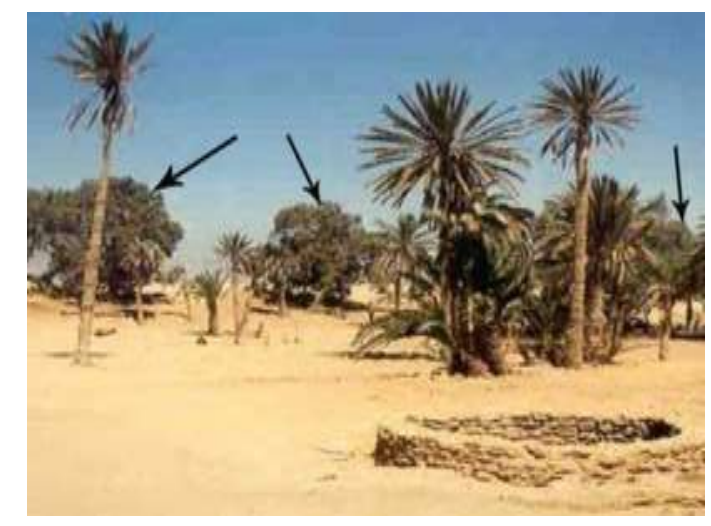

Fig. (1). T. aphylla community at the springs of Oyoun Mousa region, Sinai, Egypt.

\section{Protein Electrophoresis}

One dimensional sodium dodecyl sulfate polyacrylamide gel electrophoresis (SDS-PAGE) was conducted according to Laemmli (1970) modified by Studier (1973). Then $30 \mu \mathrm{l}$ protein extract was added to equal volume of treatment buffer. Boiling was then carried out for five minutes in a water bath before loading in the gel, and vortexed for 5-10 seconds. About 
$20 \mu \mathrm{l}$ of this mixture were loaded on the gel. Control wells were loaded with standard protein marker.

\section{Native PAGE for Isozymes}

Isoenzyme variations were identified in each of the six collected samples by using native-polyacrylamide gel electrophoresis (Native-PAGE). Four isoenzymes; $\alpha$-esterase ( $\alpha$-EST), acid phosphatase (ACPH), peroxidase (POD) and 6-phosphogluconate dehydrogenase (6-PGD) were extracted from the plant samples. These isoenzymes were separated on polyacrylamide gel according to Stegmann et al. (1985). Isozenymes were extracted from frozen plant samples $(0.4 \mathrm{~g}$ each) using $2 \mathrm{ml}$ of isoenzyme extraction buffer. Samples were transferred to Eppendorf tubes, then centrifuged at $12000 \mathrm{rpm}$ for 20 minutes at $4^{\circ} \mathrm{C}$. The supernatant liquids containing isoenzymes were transferred to clean Eppendorf tubes and stored at $-20^{\circ} \mathrm{C}$ for electrophoretic analysis. A volume of $20 \mu \mathrm{l}$ isoenzyme extract was mixed with $6 \mu \mathrm{l}(0.4 \%)$ bromophenol blue and glycerol. Twenty $\mu 1$ of each sample were loaded into the appropriate well. The gels were completely covered with an electrode buffer. The electrodes were connected to the power supply (Bio-Rad system; $100-200 \mathrm{~V}$ ) then the electrophoretic apparatus was connected to the cooling circulation (Biometra) at $4^{\circ} \mathrm{C}$.

After electrophoresis, the isoenzyme of interest was identified by incubating the gel in an appropriate substrate solution, so that a coloured product was produced at the site of the enzyme (Wilson and Walker, 2000).

For $\alpha$-EST the gel was incubated in phosphate buffer $(0.1 \mathrm{M}, \mathrm{pH}$ 7.0) for 10 minutes, and then transferred to the stain solution according to Jonathan and Wendell (1990). The gel was incubated until red or brown bands appeared, then rinsed and fixed (dark is not required).

For ACPH, the gel slice was incubated at ambient temperature for 30 minutes in a $0.05 \mathrm{M}$ sodium acetate buffer, $\mathrm{pH} 6.0$ ( $0.33 \mathrm{~g}$ sodium acetate in $50 \mathrm{ml} \mathrm{H}_{2} \mathrm{O}$ with a minor $\mathrm{pH}$ adjustment), drained, then stained as mentioned by Shaw (1970). The gel slice was then incubated in the dark until desired staining intensity has occurred.

For POD the reaction mixture was prepared according to Graham et al. (1964). The gel slice was incubated in a refrigerator for 30-60 minutes.

In the case of 6-PGD, the staining procedures to visualize 6-PGD followed the method of Vallejos (1983). After the appearance of the isozyme bands, the gel was washed with tap water to stop reaction, then kept in the fixing solution (ethanol and 20\% glacial acetic acid 1:11) for 24 hours and rinsed with tap water two times, then photographed.

\section{RAPD-PCR}

DNA isolation was carried out according to Junghans and Metzlatt (1990). Half gram to $1 \mathrm{~g}$ leaf tissue was ground in a mortar and pestle in liquid nitrogen until a fine powder was obtained, and then transferred to 1.5

Egyptian J. Desert Res., 62/63, 55-70 (2012/2013) 
$\mathrm{ml}$ Eppendorf tubes. An amount of $700 \mu \mathrm{l}$ extraction buffer was added and mixed well. The tubes were incubated at $4^{\circ} \mathrm{C}$ for ten minutes, and then centrifuged at $12000 \mathrm{rpm}$ for ten minutes. The supernatant was transferred to a new sterile Eppendorf tube, and then $500 \mu$ phenol: chloroform: isoamyl (25: 24: 1) were added to wash the supernatant. The upper phase was transferred to a new sterile $1.5 \mathrm{ml}$ tube. An amount of $500 \mu \mathrm{l}$ phenol: chloroform: isoamyl $(25: 24: 1)$ were added and mixed. The tubes were centrifuged at $12000 \mathrm{rpm}$ for five minutes. A volume of $750 \mu \mathrm{l}$ cold isopropanol were added and mixed with the aqueous phase and the tubes were incubated at $4^{\circ} \mathrm{C}$ for 15 minutes. The tubes were centrifuged for five minutes to aggregate the DNA. The pellets were washed in $70 \%$ ethanol and left to dry for about 30 minutes. The pellets were re-dissolved in $100 \mu 1 \mathrm{TE}$ buffer. Then, RNAase ( 5 units / $\mu$ l for each sample) was added to remove RNA from the samples and was incubated at $37^{\circ} \mathrm{C}$ for two hours to have pure DNA and kept in refrigerator till use.

PCR-RAPD reactions were conducted using eight arbitrary 10-mer primers (Operon Technologies, Inc) (Table 1). Amplification was carried out in Strategene Robocycler Gradient 96.

Table (1). List of the eight operon primers and their nucleotide sequence.

\begin{tabular}{cc}
\hline $\begin{array}{c}\text { Primer } \\
\text { name }\end{array}$ & Sequence \\
\hline OP-A01 & 5-CAGGCCCTTC-3 \\
OP-A04 & 5-AATCGGGCTG-3 \\
OP-A07 & 5-GAAACGGGTG-3 \\
OP-A10 & 5-GTGATCGCAG-3 \\
OP-A15 & 5-TTCCGAACCC-3 \\
OP-B01 & 5-GTTTCGCTCC-3 \\
OP-B04 & 5-GGACTGGAGT-3 \\
OP-B06 & 5-TGCTCTGCCC-3 \\
\hline
\end{tabular}

The run was performed for one hour at 100 volt using Biometra gel electrophoresis submarine $(20 \mathrm{cmx} 10 \mathrm{~cm})$. The bands were detected on UVtransilluminator and photographed by Gel documentation system (UVP) 200.

\section{RESULTS}

\section{Photosynthetic Pigments}

The changes in chl. a, chl. b and carotenoids in the two species $T$. aphylla and T. nelotica are observed in table (2). 
Table (2). Photosynthetic pigments of T. aphylla and T. nilotica expressed as $\mathrm{mg} / \mathrm{g}$ fresh weight.

\begin{tabular}{ccccc}
\hline Plant & Chl. a & Chl. b & Carotenoids & Total \\
\hline T. aphylla & 2.960 & 0.914 & 0.398 & 4.27 \\
T. nilotica & 3.682 & 0.823 & 0.476 & 4.97 \\
\hline
\end{tabular}

\section{Total Protein Analysis}

SDS-PAGE protein pattern (Fig. 3 and Table 3) indicated that there were a total of nine different bands; four of them were monomorphic bands, which gave a similarity of $44.44 \%$ among the six samples of the two species. T. aphylla expressed three bands with Rfs: $0.12,0.26$ and 0.31 , which were missing in T. nilotica.

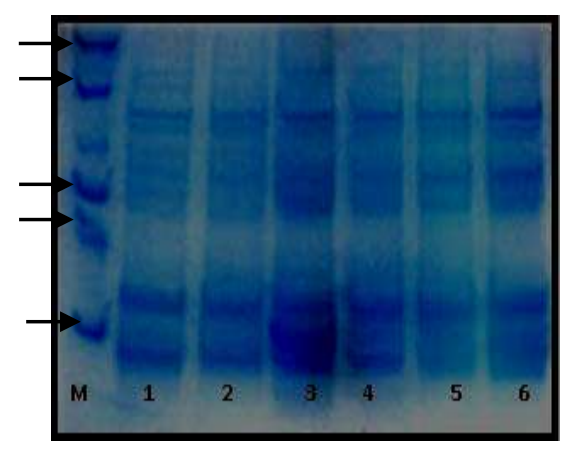

Fig. (3). SDS-PAGE of protein banding patterns of T. aphylla (samples 1, 2 \& 3) and T. nilotica (samples 4, 5 \& 6).

Table (3). SDS-PAGE of protein banding patterns of T. aphylla (samples 1, $2 \& 3$ ) and T. nilotica (samples 4, 5 \& 6).

\begin{tabular}{|c|c|c|c|c|c|c|c|c|}
\hline Band & Rf & 1 & 2 & 3 & 4 & 5 & 6 & MW \\
\hline 1 & 0.12 & - & - & + & - & - & - & 78.79 \\
\hline 2 & 0.22 & + & + & + & + & + & + & 56.23 \\
\hline 3 & 0.26 & + & + & - & - & & - & 51.08 \\
\hline 4 & $\mathbf{0 . 3 1}$ & + & - & - & - & - & - & 43.69 \\
\hline 5 & 0.37 & + & + & + & + & + & + & 35.00 \\
\hline 6 & 0.42 & - & - & + & + & + & + & 29.66 \\
\hline 7 & 0.68 & + & + & + & + & + & + & 15.87 \\
\hline 8 & 0.75 & - & - & + & + & - & + & 13.88 \\
\hline 9 & $\mathbf{0 . 8 0}$ & + & + & + & + & + & + & 12.86 \\
\hline \multicolumn{2}{|c|}{ Total } & 6 & 5 & 7 & 6 & 6 & 6 & \\
\hline
\end{tabular}

Egyptian J. Desert Res., 62/63, 55-70 (2012/2013) 


\section{Isoenzymes Expression}

Electrophoretic banding patterns of the four isoenzymes $\alpha$-EST, ACPH, POD and 6-PGD showed that ACPH and 6-PGD isoenzymes had extra bands in T. aphylla, which were not found in T. nilotica (Table 4). From 5 to 6 band forms of 6-PGD isoenzyme were detected in samples of T. aphylla, while in $T$. nilotica only 2 to 3 bands were observed. One extra esterase band was detected in T. nilotica and not found in T. aphylla. T. nilotica had more forms of esterase isoenzymes than T. aphylla (Table 4).

Table (4). Electrophoretic banding patterns of the four studied isoenzymes; Acid phosphatase (ACPH), 6-phosphogluconate dehydrogenase (6-PGD), $\boldsymbol{\alpha}$-esterase $(\alpha$-EST) and peroxidase (POD) isoenzymes found in $T$. aphylla (sample 1, $2 \& 3$ ) and T. nilotica (samples 4, 5 \& 6).

\begin{tabular}{|c|c|c|c|c|c|c|c|c|c|c|c|c|c|c|c|c|c|c|}
\hline \multirow[t]{2}{*}{ Samples } & \multicolumn{3}{|c|}{ АСРН } & \multicolumn{7}{|c|}{ 6-PGD } & \multicolumn{5}{|c|}{$\alpha-E S T$} & \multicolumn{3}{|c|}{ POD } \\
\hline & 1 & 2 & 3 & 1 & 2 & 3 & 4 & 5 & 6 & 7 & 1 & 2 & 3 & 4 & 5 & 1 & 2 & 3 \\
\hline 1 & + & - & + & + & + & - & - & + & + & + & + & - & + & - & + & + & + & + \\
\hline 2 & + & + & + & + & + & - & + & + & + & + & + & - & + & + & - & + & - & + \\
\hline 3 & + & + & + & + & + & - & - & + & + & + & + & - & + & + & - & + & - & + \\
\hline 4 & + & - & + & + & - & + & - & + & - & - & + & + & - & - & + & + & + & + \\
\hline 5 & + & - & + & + & - & + & - & - & - & - & + & + & + & + & + & + & - & - \\
\hline 6 & + & - & + & + & - & + & - & - & - & - & + & - & + & + & + & + & + & - \\
\hline
\end{tabular}

\section{RAPD-PCR Amplification}

The results presented in Fig. (4) and table (8 and 9) showed that a total of 50 bands were scored for the eight used RAPD primers for a range from 5 to 8 , corresponding to an average of 6.2 bands per primer. A percentage of $66 \%$ (33 bands) of these bands were polymorphic whereas 6 out of 33 are unique among the six samples. Data in table (8 and 9) show that five of the six unique bands were detected in $T$. aphylla, their size ranged from $355 \mathrm{bp}$ with the use of primer OPB-6 and $2139 \mathrm{bp}$ with primer OPB-4.

The number of monomorphic bands per primer ranged from one band that appeared with the primers OPA-7 and OPA-15 and three bands with the primers OPA-1, OPB-4 and OPB-6. A total of 17 monomorphic bands (34\%) were found among the six samples, their size ranged from 1881 $\mathrm{pb}$ with the primer OPB-6 to $58 \mathrm{pb}$ with the use of the primer OPB-4.

The use of DNA markers OPA-7, OPA-10, OPA-15 and OPB-4 distinguished high molecular weight bands with size ranging from 2500$1090 \mathrm{bp}$ in T. aphylla only and absent in T. nilotica. While the markers OPA1 and OPB-1 showed bands with size 690, 950 and 945 bp in T. nilotica only, the markers OPA-4 and OPB-6 showed bands in T. aphylla with size 635 and 355 bp and bands with size 660 and 514 bp in T. nilotica (Table 8 and 9). 


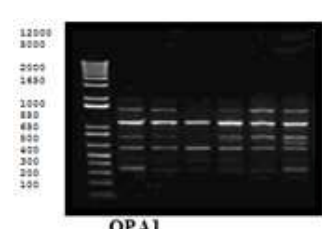

OPA

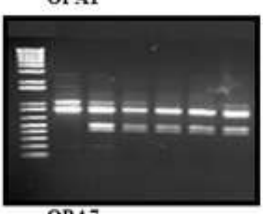

OPA7

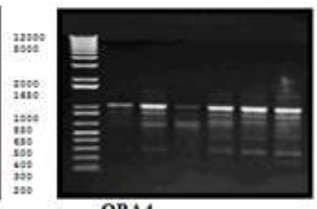

OPA4

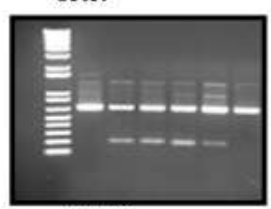

OPA10

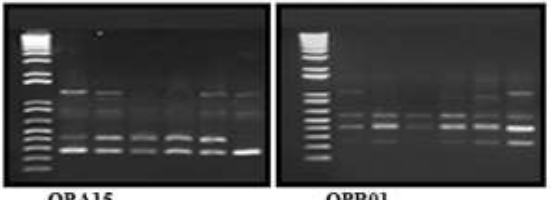

OPB01

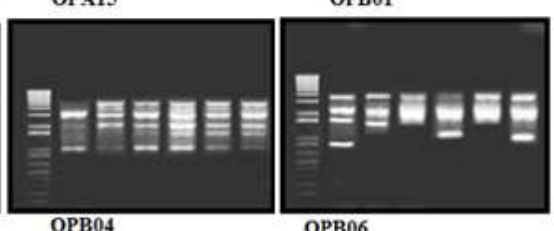

OPB04

OPB06

Fig. (4). Amplified DNA fragments of T. aphylla (sample 1, $2 \& 3$ ) and $T$. nilotica (samples $4,5 \& 6$ ) produced by eight primers.

Table (8). Polymorphic amplified DNA fragments of T. aphylla (sample 1, 2 $\& 3$ ) and T. nilotica (samples 4, $5 \& 6$ ) produced by eight primers. $0=$ absence of band, $1=$ presence of band.

\begin{tabular}{|l|c|c|c|c|c|c|c|c|c|}
\hline $\begin{array}{c}\text { DNA } \\
\text { marker }\end{array}$ & $\begin{array}{c}\text { Size } \\
(\mathrm{bp})\end{array}$ & 1 & 2 & 3 & 4 & 5 & 6 \\
\hline \multicolumn{7}{|c|}{ OPA-1 } \\
\hline AF01 & 1960 & 1 & 1 & 0 & 1 & 1 & 1 \\
\hline AF03 & 810 & 1 & 1 & 0 & 1 & 1 & 1 \\
\hline AF04 & 690 & 0 & 0 & 0 & 0 & 0 & 1 \\
\hline \multicolumn{7}{|c|}{ OPA-4 } \\
\hline AF07 & 1430 & 0 & 1 & 0 & 1 & 1 & 1 \\
\hline AF10 & 660 & 0 & 0 & 0 & 1 & 1 & 1 \\
\hline AF11 & 635 & 1 & 1 & 1 & 0 & 0 & 0 \\
\hline AF12 & 465 & 0 & 0 & 0 & 1 & 1 & 1 \\
\hline AF13 & 250 & 0 & 1 & 0 & 1 & 1 & 1 \\
\hline \multicolumn{7}{|c|}{ OPA } & -7 \\
\hline AF14 & 2500 & 1 & 0 & 0 & 0 & 0 & 0 \\
\hline AF15 & 1760 & 1 & 0 & 0 & 0 & 0 & 0 \\
\hline AF16 & 1040 & 1 & 1 & 1 & 0 & 0 & 1 \\
\hline AF18 & 480 & 0 & 1 & 1 & 1 & 1 & 1 \\
\hline AF19 & 440 & 0 & 1 & 1 & 1 & 1 & 1 \\
\hline
\end{tabular}

\begin{tabular}{|c|c|c|c|c|c|c|c|}
\hline $\begin{array}{c}\text { DNA } \\
\text { marker }\end{array}$ & $\begin{array}{c}\text { Size } \\
(\mathrm{bp})\end{array}$ & 1 & 2 & 3 & 4 & 5 & 6 \\
\hline \multicolumn{7}{|c|}{ OPA-10 } \\
\hline AF20 & 1655 & 1 & 0 & 0 & 0 & 0 & 0 \\
\hline AF22 & 1000 & 1 & 0 & 0 & 1 & 1 & 0 \\
\hline AF23 & 670 & 1 & 1 & 1 & 1 & 1 & 1 \\
\hline AF24 & 200 & 0 & 1 & 1 & 1 & 1 & 0 \\
\hline \multicolumn{7}{|c|}{ OPA-15 } \\
\hline AF25 & 1260 & 1 & 1 & 0 & 0 & 1 & 1 \\
\hline AF26 & 1090 & 0 & 1 & 0 & 0 & 0 & 0 \\
\hline AF27 & 850 & 1 & 1 & 0 & 0 & 1 & 1 \\
\hline AF28 & 710 & 1 & 1 & 0 & 0 & 1 & 1 \\
\hline AF29 & 430 & 1 & 1 & 1 & 1 & 1 & 0 \\
\hline \multicolumn{7}{|c|}{ OPB-1 } \\
\hline AF31 & 1675 & 1 & 1 & 0 & 1 & 1 & 1 \\
\hline AF32 & 1550 & 1 & 1 & 0 & 1 & 1 & 1 \\
\hline AF33 & 1075 & 1 & 0 & 0 & 0 & 0 & 1 \\
\hline AF34 & 950 & 0 & 0 & 0 & 1 & 1 & 1 \\
\hline AF35 & 645 & 0 & 0 & 0 & 0 & 1 & 1 \\
\hline AF38 & 220 & 1 & 1 & 0 & 1 & 1 & 1 \\
\hline
\end{tabular}

\begin{tabular}{|c|c|r|c|c|c|c|c|c|}
\hline $\begin{array}{c}\text { DNA } \\
\text { marker }\end{array}$ & $\begin{array}{c}\text { Size } \\
\text { (bp) }\end{array}$ & 1 & 2 & 3 & 4 & 5 & 6 \\
\hline \multicolumn{8}{|c|}{ OPB-4 } & \\
\hline AF39 & 2139 & 1 & 0 & 0 & 0 & 0 & 0 \\
\hline AF40 & 1207 & 0 & 1 & 1 & 1 & 1 & 1 \\
\hline AF41 & 783 & 0 & 1 & 0 & 1 & 1 & 1 \\
\hline AF44 & 158 & 0 & 0 & 1 & 1 & 1 & 1 \\
\hline \multicolumn{8}{|c|}{ OPB-6 } \\
\hline AF49 & 514 & 0 & 0 & 0 & 1 & 0 & 1 \\
\hline AF50 & 355 & 1 & 0 & 0 & 0 & 0 & 0 \\
\hline
\end{tabular}

Egyptian J. Desert Res., 62/63, 55-70 (2012/2013) 
Table (9). Number and types of the amplified DNA bands as well as the percentage of the total polymorphism generated by eight primers.

\begin{tabular}{|c|c|c|c|c|c|}
\hline \multirow[b]{2}{*}{$\begin{array}{l}\text { Primer } \\
\text { code }\end{array}$} & \multirow[b]{2}{*}{$\begin{array}{l}\text { Monomorphic } \\
\text { bands }\end{array}$} & \multicolumn{2}{|c|}{ Polymorphic } & \multirow[b]{2}{*}{$\begin{array}{r}\text { Total } \\
\text { bands }\end{array}$} & \multirow[b]{2}{*}{$\begin{array}{c}\text { Polymorphic } \\
\%\end{array}$} \\
\hline & & Unique & $\begin{array}{c}\text { Non } \\
\text { unique }\end{array}$ & & \\
\hline OPA-1 & 3 & 3 & - & 6 & 50.0 \\
\hline OPA-4 & 2 & - & 5 & 7 & 71.4 \\
\hline OPA-7 & 1 & 4 & 1 & 6 & 83.3 \\
\hline OPA-10 & 2 & 1 & 2 & 5 & 60.0 \\
\hline OPA-15 & 1 & 2 & 3 & 6 & 83.3 \\
\hline OPB-1 & 2 & 2 & 4 & 8 & 75.0 \\
\hline OPB-4 & 3 & 2 & 2 & 7 & 57.1 \\
\hline OPB-6 & 3 & 1 & 1 & 5 & 40.0 \\
\hline
\end{tabular}

\section{DISCUSSION}

It is clearly shown from the results of the presented comparative study that the photosynthetic pigments in $T$. aphylla are relatively lower than that in T. nilotica. This decrease may be due to the very old age of $T$. aphylla, giant shoot, more wind pressure, and demand to large amount of water than the small juvenile tree of T. nilotica. These results agree with that of Mohamed et al. (2010) who found in Solanum tuberosum L. that NaClstress caused significant reduction in the content of chlorophyll a, chlorophyll b and total carotenoids. Also, Parida and Das (2005) stated that salt stress inhibits photosynthesis, suppresses growth, affects protein synthesis, and alters energy and lipid metabolism.

The relatively moderate soil salinity of plant habitats $(3680 \mathrm{ppm})$ is due to the winter time of sampling after heavy rains on this Egyptian region. Normally, salinity increases during summer in all Sinai, the recorded average in this study is the minimum salinity level during year period.

Several investigations have shown the synthesis of new proteins in plant cells when subjected to salinity stress (Ericson and Alfinito, 1984; Hurkman and Tanaka, 1987; Singh et al., 1987 and El-Meleigy et al., 2004). The levels of proteins differ in salt-tolerant and salt-sensitive genotypes when they are subjected to salinity stress (Dubey and Rani, 1989). It is well established that salt tolerance and sensitivity depend on genetic and biochemical composition of the species. Salt stress caused an induction in the synthesis of some new polypeptide bands (El-Meleigy et al, 2004; Hassanein, 2004 and Mohamed et al., 2010).

In this study, SDS-PAGE of the total extractable proteins of the two investigated Tamarex spp. showed remarkable variations in protein patterns among the two species. Concerning the number of protein bands, three polypeptide bands with $\mathrm{R}_{\mathrm{f}} 0.12,0.26$ and 0.31 and different molecular 
weights (KDa) were synthesized in $T$. aphylla in response to salinity stress. These results are in agreement with those of El-Meleigy et al. (2004), Hassanein (2004) and Mohamed et al. (2010). Quantitative differences in band intensities of the two genotypes indicated higher intensities in $T$. aphylla than $T$. nilotica. These proeins, specifically synthesized under salt stress, appear to have a role in providing tolerance or adaptation to the plants, which might indicate that $T$. aphylla is more salt-tolerant than $T$. nilotica.

Isoenzymes are a more sensitive biochemical factors than morphological index as they appear much earlier attribute (Li et al., 1985). Isoenzymes are important, because they can help to understand how each stress affects the different sub-cellular compartments (Scandalios, 1993). The utilization of multiple isoforms of enzymes is one of the primary control mechanisms of cellular metabolism in plants (Mohamed et al., 2010).

The induction of new isoenzymes and the change in the isoenzyme profile are considered to play an important role in the cellular defense against oxidative stress, caused by salt stress (Mohamed et al., 2010).

The results of the electrophoretic profiles of the four isoenzymes showed that $T$. apylla had extra bands of the ACPH, and 4 extra bands of 6PGD, which were not found in T. nilotica. Electrophoetic banding patterns of 6PGD showed a total of 7 forms; four bands were found in T. aphylla but not found in T. nilotica. These results are in a harmony with those of Kaplan (2007) who found that 6PGD (dimer) was the most informative enzyme system, and therefore deserved an analysis of alleles, where two loci were detected, which formed intergenic heterodimers giving rise to multibanded isoenzyme patterns.

T. aphylla showed an increase in the staining intensity of POD bands than in T. nilotica. This finding is in agreement with those found in different tolerant plants by many investigators, for example Halimione portulacoides by Kalir et al. (1984). Sreenivasulu et al. (2000) stated that higher peroxidase isoenzymes were detected in salt tolerant cultivars compared to salt susceptible cultivar of Fox-Tail millet, tolerant cultivars of wheat (Moghaieb et al., 2010), Allium cepa (Abd El-baky et al., 2010) and Tamarix hispida (Wang et al., 2010). Peroxidase playes an important role in the prevention of oxidative damage caused by environmental stress to the membrane lipids (Kalir et al., 1984 and Chen et al., 2007).

An extra $\alpha$-EST band was detected in T. nilotica, which was not found in T. aphylla. T. nilotica has more forms of $\alpha$-EST isoenzymes than T. aphylla. These results are in agreement with those of Hassanein (2004) who found that the response of EST is less in tolerant than sensitive plants. He stated that the number/ or staining intensity of esterase was affected by atrazine stress in atrazine sensitive more than atrazine resistant. 
The use of random primers in a PCR is a powerful tool that reveals extensive DNA polymorphism, and it has become valuable in genetic analysis.

In the present study, six samples from the two species were studied using RAPD markers. A total of 50 bands were scored for the 8 RAPD primers for a range from 5 to 8 , corresponding to an average of 6.2 bands per primer. 34\% (17 bands) were monomorphic, while 66\% (33 bands) of these were polymorphic

The number of monomorphic bands per primer ranged from one band with each of the primers OPA-7 and OPA-15 to three bands with the primers OPA-1, OPB-4 and OPB-6. The monomorphic bands are constant bands and cannot be used to study diversity while polymorphic bands reveal differences and can be used to examine and establish systematic relationships among the genotypes (Hadrys et al., 1992).

The variation in the number of bands amplified by different primers ws influenced by variable factors such as primer structure, template quantity and less number of annealing sites in the genome.

The use of DNA markers, OPA-7,OPA-10, OPA- 15 and OPB-4 distinguished fragments of about (2500, 2139, 1760, 1655 and $1090 \mathrm{bp}$ ) respectively in T. aphylla while were absent in T. nilotica (Table 5). These genetical variations between the two species might suggest that these primers has the ability to produce salinity tolerant markers in T. aphylla Than T. nilotica. They can be considered as positive salt tolerant markers and can be used to identify salt tolerant genotypes. In this respect, many investigators exploited DNA markers and detected some markers to abiotic stress.In this connection, Pakniyat and Tavakol (2007) found markers related to drought tolerance in bread wheat genotypes using RAPD markers. Pakniyat et al. (2004) introduced markers linked to salt tolerance in cultivated and wild barley using these markers. Also, Nazari and Pakniyat (2008) also found markers associated with drought tolerance in wild and cultivated barley genotypes using RAPD markers. Youssef et al. (2010) found molecular markers for new promising drought tolerant lines of rice under drought stress via RAPD-PCR.

\section{CONCLUSION}

The electrophoretic analysis of total protein, isoenzymes and RAPD-PCR for the six samples of T. aphylla and T. nilotica revealed that the two studied species are tolerant to salt stress. The presence of more banding of total protein, ACPH, 6PGD, isoenzymes and high intensity stained bands of POD, polymorphic bands of RAPD in $T$. aphylla and absent in T. nilotica might suggest that, T. aphylla plants are more tolerant to salt stress than T. nilotica. This might be further 
accomplished by increasing the capacity of antioxidative system and the synthesis of new proteins and isoenzymes which could in turn contribute to some defense mechanisms of tolerant plant. More advanced molecular studies must be suggested for these assumed tolerant genes.

\section{ACKNOWLEDGEMENT}

The authors are sincerely appreciative for Prof. Dr. El-Sayeda Gamal El-Dein for taxonomical identification of the samples.

\section{REFERENCES}

Abd El-baky, H.H., A.A. Mohamed and M.M. Hussein (2010). Influence of salinity on lipid peroxidation, antioxidant enzymes and electrophoretic patterns of protein and isoenzymes in leaves of some onion cultivars. Asian Journal of Plant Sciences, 2(8): 633- 638

Borsani, O., V. Valpuesta and M.A. Botella (2001). Evidence for a role of salicylic acid in the oxidative damage generated by $\mathrm{NaCl}$ and osmotic stress in Arabidopsis seedlings. Plant Physiol., 126: 1024-1030.

Brock, J.H. (1994). Tamarix spp. (Salt Cedar), In “An Invasive Exotic Woody Plant in Arid and Semi-arid Riparian Habitats of Western USA". p. 27-44. Ecology and Management of Invasive Riverside Plants (de Waal L.C., L.S. Child, P.M. Wade and J.H. Brock, eds.). John Wiley \& Sons, Chichester, 217 pp.

Chen, C., C. Tao, H. Peng and Y. Ding (2007). Genetic analysis of salt stress responses in asparagus Bean (Vigna unguiculata (L.) ssp. sesquipedalis verdc.). J. Heredity, 98(7):655-665.

Cleverly, J.R., S.D. Smith, A. Sala, and D.A. Devitt (1997). Invasive capacity of Tamarix ramosissima in a Mojave Desert floodplain: the role of drought. Oecologia, 111:12-18.

Demiral, T. and I. Turkan (2005). Comparative lipid peroxidation, antioxidant defense systems and proline content in roots of two rice cultivars differing in salt tolerance. Environ Exp Botany, $53: 247-257$.

Di Tomaso, J.M. (1996). Identification, biology and ecology of salt cedar. Proceedings of the Saltcedar Managemen Workshop. June 12, 1996, Rancho Mirage, California, Dittberner, Phillip.

Dubey, R.S. and M. Rani (1989). Influence of $\mathrm{NaCl}$ salinity on growth and metabolic status of proteins and amino acids in rice seedlings. J. Agron. Crop Sci., 126:97.

Egyptian J. Desert Res., 62/63, 55-70 (2012/2013) 
El-Meleigy, S.A., M.F. Gabr, F.H. Mohamed and M.A. Ismail (2004). $\mathrm{NaCl}$-induced proteins in tomato genotypes differing in salt tolerance. Proceedings, Egyptian Botanical Society Conference, Stress in Plants, Ain Shams University, Cairo, March $3^{\text {rd }} 2004$, p. 52-73.

Ericson, M.C. and S.H. Alfinito (1984). Proteins produced during salt stress in tobacco cell culture. Plant Physiol., 74:504.

Glenn, E. and P. Nagler (2005). Comparative ecophysiology of Tamarix ramosissima and native trees in western U.S. riparian zones. Journal of Arid Environments, 61:419-446.

Glenn, E., R. Tanner, S. Mendez, T. Kehret, D. Moore, J. Garcia and C. Valdes (1998). Growth rates, salt tolerance and water use characteristics of native and invasive riparian plants from the delta of the Colorado River delta, Mexico. Journal of Arid Environments, 40:281-294.

Graham, R.C., U. Ludholm and M.J. Kamovsky (1964). Cytochemical demonstration of peroxidase activity with 3-amino-9ethylcarbazole. J. Histochem. \& Cytochem., 13:150-152.

Hadrys, H., M. Balick and B. Schierwater (1992). Application of random Amplified polymorphic DNA (RAPD) in molecular ecology. Mol. Ecol., 1:55-60.

Hassanein, A.M. (2004). Effect of relatively high concentrations of manitol and sodium chloride on regeneration and gene expression of stress tolerant (Alhagi graecorum) and stress sensitive (Lycopersicon esculentum L.) plant species. Bulg. J. Plant Physiol., 30(3-4):19-36.

Huang, Y., Z. Bie, Z. Liu, A. Zhen and W. Wang (2009). Protective role of proline against salt stress is partially related to the improvement of water status and peroxidase enzyme activity in cucumber. Soil Science and Plant Nutrition, 55:698-704.

Hurkman, W.J. and C.K. Tanaka (1987). The effect of salt on the pattern of protein synthesis in barley roots. Plant Physiol., 83:517-524.

Jonathan, F.W. and N.F. Wendell (1990). In "Visulization and Interpretation of plant Isozymes". Isozymes in Plant Biology (Soltis, D.E., ed.). London Champan and Hall, pp. 5-45

Junghans, S. and M. Metzlatt (1990). A simple and rapid method for the preparation of total plant DNA. Biotechniques, 8:176.

Kalir, A., G. Omri and A. Poljakoff-Mayber (1984). Peroxidase and catalase activity in leaves of Halimione portulacoides exposed to salinity. Physiologia Plantarum, 62:238-244.

Kaplan, Z. (2007). First record of Potamogeton salicifolius for Italy, with isozyme evidence for plants collected in Italy and Sweden. Plant Biosystems, 141(3):344-351. 
Laemmli, U.K. (1970). Cleavage of structural proteins during the assembly of the head of bacteriophage T4. Nature, 227:680-685.

Li, G.F., Z. Liang, G.Z. Li, X. Zhang and B.G. Yu (1985). Analysis of isozymes in barley (Hordeum vulgare) bin mutations induced by magnetic fields. Acta Biochem. Biophys. Sin., 17:476-483.

Meloni, D.A., M.A. Oliva, C.A. Martinez and J. Cambraia (2003). Photosynthesis and activity of superoxide dismutase, peroxidase and glutathione reductase in cotton under salt stress. Environ. Exp. Bot., 49:69-76.

Metzner, H., H. Rau and H. Senger (1965). Untersuchungen Zur synchronixier Barkelt Einzelner Pigment Mangel. Multantent Von Chlorella. Planta, 65:186.

Moghaieb, R.E.A., B.T. Neveen, A.A. Abdel-Hadi, S.S. Youssef and A.M. El-Sharkawy (2010). Genetic variation for salt tolerance in some bread and pasta wheat genotypes. Arab J. Biotech., 13(1): 125-142.

Mohamed, A.A, M.A. Matter and M.M. Saker (2010). Effect of salt stress on some defense mechanisms of transgenic and wild potato clones (Solanum tuberosum L.) grown in vitro. Nature and Science, 8(12): 181-193.

Munns, R. (2005). Genes and salt tolerance: bringing them together. New Phytologist., 167:645-663.

Nazari, N. and H. Pakniyat (2008). Genetic diversity of wild and cultivated barley genotypes under drought stress using RAPD markers. Biotechnology, 7(4): 745-750.

Pakniyat, H. and E. Tavakol (2007). RAPD markers ssociated with drought tolerance in bread wheat (Triticum aestivum L.). Pak. Biol. Sci., 10: 3237-3239.

Pakniyat, H., A. Namayandeh and B.P. Forster (2004). Identification of RAPD markers linked to salt tolerance in cultivated and wild barley. Proceedings of the 9th International Barley Gentics Symposium, Brono, Czech Republic, p. 191-194.

Parida, A.K. and A. Das (2005). Salt tolerance and salinity effects on plants: a review. Ecotoxicology and Environmental Safety, 60: 324349.

Sairam, R.K. and A. Tyagi, (2004). Physiology and molecular biology of salinity stress tolerance in plants. Current Science, 86:407-421.

Scandalios, J.G. (1993). Oxygen stress and superoxide dismutases. Plant Physiol., 101: 1-7.

Shalata, A., V. Mittova, M. Volokita, M. Guy and M. Tal (2001). Response of cultivated tomato and its wild salt-tolerant relative Lycopersicon pennelli to salt-dependent oxidative stress: the root antioxidative system. Physiologia Plantarum, 122: 487494.

Egyptian J. Desert Res., 62/63, 55-70 (2012/2013) 
Shaw, E. (1970). In "Enzymes". $3^{\text {rd }}$ ed. Vol. 1 (Boyer, P., ed.). Academic Press, New York, pp. 91-147

Singh, N.K., C.A. Bracker, P.M. Hasegawa, A.K. Handa, S. Buckel, M.A. Hermodson, E. Pfankoch, F.E. Regnier and R.A. Bressan (1987). Characterization of osmotin, a thoumatin-like protein associated with osmotic adaptation in plant cells. Plant Physiol., 85: 529-536.

Sreenivasulu, N., B. Grimm, U. Wobus and W. Weschke (2000). Differential response of antioxidants to salinity stress in salt tolerant and salt sensitive seedlings of foxtail millet (Setaria italica). Physiol Plant., 109: 435-442.

Stegmann, H., W. Burgermeister, H. Francksen and F. Krogerrecklen (1985). In "Manual of Gel Electrophoresis and Isoelectric Focusing with the Apparatus PANTA-PHOR". INST. Biochem., Messeweg 11, D-3300 Braunschweig, Germany.

Studier, W.E. (1973). Genetic analysis of non-essential bacteriophage T7 genes. J. Mol. Biol., 79: 227-236.

Vallejos, E. (1983). Enzyme Activity Staining. In "Isozymes in Plant Genetics and Breeding, Part A" (Tanksley S.D. and T.J. Orton, eds.). Elsevier, Amesterdam, p. 469-516.

Vandersande, M.W., E.P. Glenn and J.L. Walworth (2001). Tolerance of five riparian plants from the lower Colorado River to salinity, drought and inundation. Journal of Arid Environments, 49: 147-159.

Wang, Y., C. Gao, Y. Liang, C. Wang, C. Yang and G. Liu (2010). A novel bZIP gene from Tamarix hispida mediates physiological responses to salt stress in tobacco plants. J. Plant Physiol., 167(3): 222-230.

Welsh J. and M. McClelland (1990). Fingerprinting genomes using PCR with arbitrary primers. Nucl. Acids Res., 18: 7213-7218.

Western, A.C. and W. McLeod Source (1995). Woods used in Egyptian bows and arrows. J. Egyptian Archaeology, 81: 77-94.

Williams, J.G.K., A.R. Kubelik, K.J. Livak, J.A. Rafalski and S.V. Tingey (1990). DNA polymorphism amplified by arbitrary primers are useful as genetic markers. Nucleic Acids Res., 18: 6531-6535.

Wilson, K. and J. Walker (2000). In "Principles and Techniques of Practical Biochemistry". $5^{\text {th }}$ ed. Published by Cambridge University Press.

Youssef, M.A., A. Mansour and S.S. Solliman (2010). Molecular markers for new promising drought tolerant lines of rice under drought stress via RAPD-PCR and ISSR markers. Journal of American Science, 6(12): 355-363.

Zahran, M.A. and Willis, A.J. (2008). In "The Vegetation of Egypt". Springer, 2008-Science, $437 \mathrm{pp}$. 


\title{
الإختلافات الوراثية والفسيولوجية بين نوعى نبات الطرفاء تماريكس أفيلا وتماريكس نيلوتيكا نوين
}

\author{
ليلى الحسينى مكي" والسيد عبد الستار المليجي

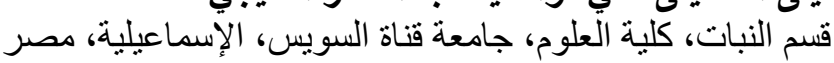

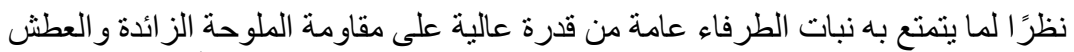

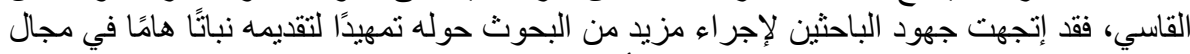

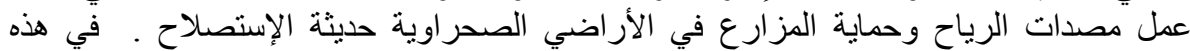

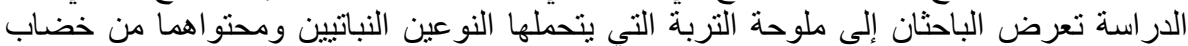

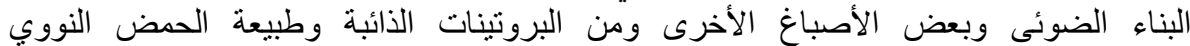

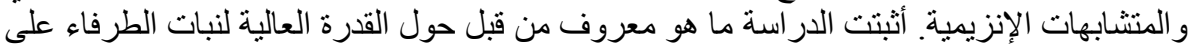

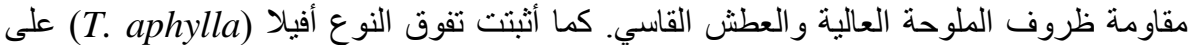

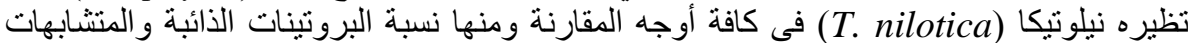

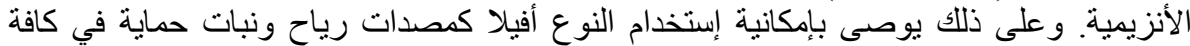

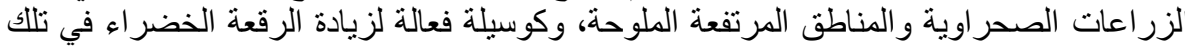
المناطق، ومصدرًا إقتصاديًا للمو اد العضوية وما تحتو يهيه من طاقة تمثيلية مختزنة.
\end{abstract}


